\title{
LATIN LEGAL MAXIMS IN THE JUDGMENTS OF THE CONSTITUTIONAL TRIBUNAL IN POLAND
}

\begin{abstract}
The article contains a list and brief characteristics of Latin legal maxims used in the judgments of the Constitutional Tribunal in Poland. Most of them were formulated by Roman jurists, some by medieval lawyers, and some by representatives of the modern science of law based on Roman law sources. They express universal and eternal ideas and are a significant element of the axiology of law. The presence of Latin legal maxims in the judgments of the Constitutional Tribunal demonstrates that Latin is an important element of the cultural heritage of ancient Rome and its knowledge is one of the essential tools in the workshop of a contemporary lawyer.
\end{abstract}

Keywords: legal Latin, legal maxims, the Constitutional Tribunal.

\section{Introduction}

Latin is one of extremely significant elements of the cultural heritage of ancient Rome. As a result of numerous wars, the steady conquering of areas by the Roman empire contributed to the expansion of Latin over areas beyond the Appenine Peninsula. Latin became the official language of the vast Imperium Romanum, although this process was not the same in respective areas (Safarewicz, 1986, 104-105). The collapse of the Roman Empire did not affect the popularity of Latin as a language spoken. The approval of Latin as the language of the Catholic church contributed significantly to the common use of Latin among various layers of the society and communities. However, one cannot disregard the fact that lingua Latina has been since then interlinked with the Roman law. The Roman law exercised by ancient Romans played a major role in the process of the European legal culture gaining shape (Stein, 1999) and its influence is visible in the contemporary legal systems (Hamza, 2013, 5-543). For centuries teaching Latin has been a core element in the educational processes of many civilised societies. In 
the times of medieval and modern Europe Latin was (and has been) spoken in the world of diplomacy, science and literature (Sondel, 1997, IX). Latin has been the language of new legal regulations and court decisions. Therefore, a profound knowledge of Latin has been an indispensable tool to perform the duties of the lawyer's profession for every lawyer. Latin legal maxims are used in the judgments of Polish courts (the Supreme Court, the Supreme Administrative Court, appeal courts, regional courts, voivodship administrative courts), in substantiation of various motions and legal opinions, and constitute an important element of legal rhetoric (Wołodkiewicz, 2001, 7-30).

The year 2016 is the year of the thirtieth anniversary of the commencement of the judicial activity of the Constitutional Tribunal in Poland. In this period, the Tribunal dealt with many legal problems, as manifested in its extensive collection of judgments. The Tribunal's resolutions, decisions, and verdicts contain numerous references to Latin legal maxims.

The purpose of this document is to indicate which rules expressing the fundamental principles of law are the most often referred to in their Latin wording in the Tribunal's judgments. In quoting the individual maxims, the author endeavours, whenever possible, to specify their authors and origins. Also, the essence of each maxim is briefly explained. The list that shows the frequency of presence of Latin maxims in the judgments of the Tribunal was prepared based on the LEX legal information system published by Wolters Kluwer. The body of the article is preceded by basic information related to the organization and functions of the Polish Constitutional Tribunal.

\section{The organization and functions of the Polish Constitutional Tribunal}

According to Article 194, para. 1 of the Constitution of the Republic of Poland of 1997, the Constitutional Tribunal is composed of 15 judges chosen individually by the Sejm for a term of office of 9 years from amongst persons distinguished by their knowledge of the law. No person may be chosen for more than one term of office. Judges of the Constitutional Tribunal, in the exercise of their office, is independent and subject only to the Constitution (Article 195, para. 1).

The Constitutional Tribunal adjudicates regarding the following matters (Article 188): 
1) the conformity of statutes and international agreements to the Constitution;

2) the conformity of a statute to ratified international agreements whose ratification required prior consent granted by statute;

3) the conformity of legal provisions issued by central State organs to the Constitution, ratified international agreements and statutes;

4) the conformity to the Constitution of the purposes or activities of political parties;

5) complaints concerning constitutional infringements, as specified in Article 79 , para. 1 .

Moreover, the Constitutional Tribunal settles disputes over authority between central constitutional organs of the State (Article 189) and determines whether or not exists an impediment to the exercise of the office by the President of the Republic (Article 131, para. 1). It should be emphasized that judgments of the Constitutional Tribunal have of universally binding application and are final. Judgments of the Constitutional Tribunal regarding matters specified in Article 188, are required to be immediately published in the official publication in which the original normative act was promulgated. If a normative act has not been promulgated, then the judgment is published in the Official Gazette of the Republic of Poland, Monitor Polski. According to Article 190, para. 5, judgments of the Constitutional Tribunal are made by a majority of votes.

The following may make application to the Constitutional Tribunal regarding matters specified in Article 188:

1) the President of the Republic, the Marshal of the Sejm, the Marshal of the Senate, the Prime Minister, 50 Deputies, 30 Senators, the First President of the Supreme Court, the President of the Supreme Administrative Court, the Public Prosecutor-General, the President of the Supreme Chamber of Control and the Commissioner for Citizens' Rights;

2) the National Council of the Judiciary, to the extent specified in Article 186, para. 2;

3) the constitutive organs of units of local government;

4) the national organs of trade unions as well as the national authorities of employers' organizations and occupational organizations;

5) churches and religious organizations;

6) the subjects referred to in Article 79 to the extent specified therein. According to Article 79, para. 1:

In accordance with principles specified by statute, everyone whose constitutional freedoms or rights have been infringed, has the right to appeal to the Constitutional Tribunal for its judgment on the conformity to the Con- 
stitution of a statute or another normative act upon which basis a court or organ of public administration has made a final decision on his freedoms or rights or on his obligations specified in the Constitution.

The subjects referred to in para. 1, subparas. 3-5 above, may make such application if the normative act relates to matters relevant to the scope of their activity. Moreover, according to Article 193, any court may refer a question of law to the Constitutional Tribunal as to the conformity of a normative act to the Constitution, ratified international agreements or statute, if the answer to such question of law will determine an issue currently before such court (Naleziński, 2014, 407-427).

\section{Latin legal maxims in the judgments of the Constitutional Tribunal}

The following list presents Latin legal maxims arranged according to their frequency in the Tribunal's judgments.

1) The maxim $\boldsymbol{n e}$ bis in idem (not twice in the same thing - 486 references) is based on a fragment of text from Gaius's Institutes (G. 4, 107). According to the judgments of the Constitutional Tribunal, this fundamental principle of penal law is an element of the principle of law-abiding state. It prohibits repeated (multiple) punishment (use of a repressive measure) of the same individual for committing one offense. This is because repeated (multiple) punishment of the same individual for the same act violates the principle of proportionality of the state's response to violations of legal obligations (the judgment of the Constitutional Tribunal of 18 November 2010, ref. No. P 29/09).

2) The post-Roman sentence lex retro non agit (the law is not retroactive -196 references) expresses the principle, deeply rooted in the law of the ancient Rome (C. 1, 14, 7; C. Th. 1, 1, 3), that law does not act retroactively (Wołodkiewicz, 2001, 153-192). In one of its judgments, the Tribunal described this principle as an important element of the legal culture of contemporary civilized states and a principal component of the constitutional order of contemporary constitutional systems of government (the judgment of the Constitutional Tribunal of 3 October 2001, ref. No. K 27/01).

3) The maxim nullum crimen, nulla poena sine lege; also nullum crimen, nulla poena sine lege poenali anteriori (no crime, no punishment without a previous law authorizing it -68 references) is one of the most important principles of contemporary penal law. On many occasions, the Tribunal emphasized that this principle constitutes the foun- 
Latin Legal Maxims in the Judgments of the Constitutional Tribunal...

dation of a democratic state (the judgment of the Constitutional Tribunal of 6 October 2015, ref. No. SK 54/13). The importance of this principle is confirmed by the fact that it can be found in Article 42, para. 1 of the Constitution of the Republic of Poland of 1997 (Cieslewicz, Sykuna, 2009, 125).

4) The maxim pacta sunt servanda (agreements must be kept 37 references) was formulated in the medieval canon law based on the words of Ulpianus (D. 2, 14, 7, 7). The Constitutional Tribunal considered it to be, without any doubt, the basic principle of our law that characterizes a lawabiding state, even in spite of its lack of absolute applicability (the judgment of the Constitutional Tribunal of 17 December 1997, ref. No. 22/96).

5) The maxim clara non sunt interpretanda (what is clear does not need interpretation - 31 references) is a post-Roman principle. The Constitutional Tribunal explained that a need for interpretation may result from an insufficiently precise formulation of a judgment, its incorrect understanding by a party to the procedure, conflicting positions of the parties concerning the contents of the judgment, or doubts related to the execution (specific direct legal consequences) of the judgment. Such doubts should be significant (serious) and objective. Thus, they cannot be solely subjective doubts of a party that requests interpretation (the judgment of the Constitutional Tribunal of 13 November 2002, ref. No. SK 28/01).

6) The sentence ignorantia iuris nocet (ignorance of the law does not excuse -20 references) is an abbreviated version of a statement made by a Roman jurist, Paulus (D. 22, 6, 9 pr.; see also Wołodkiewicz, 2001, 109-126). In its judgments, the Constitutional Tribunal indicated that publication of a normative act in the official journal leads to the assumption that the content of a regulation is universally known. It assumes that all addressees of the applicable legal norm - both entities obligated to observe it and bodies established to apply it - know its true content. As a result, no one can avoid the negative consequences of violations of the norm by saying that he or she did not know it or had an incorrect understanding of the norm (the judgment of the Constitutional Tribunal of 21 April 2009, ref. No. Ts $167 / 08)$.

7) The maxim exceptiones non sunt extendendae (exceptions cannot be extended -20 references) is one of the fundamental principles of interpretation of law (Zajadło, 2009, 28-29). The Tribunal indicated that if a law provides for an exception to a general principle introduced by another regulation, then such an exception must not be interpreted in a broad manner (the judgment of the Constitutional Tribunal of 5 June 2001, ref. No. K 18/00). 
8) The sentence in dubio pro reo (in a doubtful case, in favor of the defendant - 19 references) is based on numerous Roman law sources (D. $44,7,47$; D. $48,19,5$ pr.; D. 50, 17, 125). It means that a defendant (or accused in disciplinary proceedings) does not have to prove anything because the burden of proof of an allegation lies with the authorities that conduct the proceedings. When the hearing of evidence does not result in clarification of circumstances of the case that are important to overcome the presumption of innocence, all doubts should be resolved to the advantage of the defendant (the judgment of the Constitutional Tribunal of 27 February 2001, ref. No. K 22/00).

9) The maxim actor sequitur forum rei (the claimant follows the court of the defendant - 18 references) is based on the constitution of 293 of emperors Diocletian and Maximian (C. 3, 13, 2); on the constitution of 385 of emperors Gratian, Valentinian, and Theodosius (C. 3, 19, 3); Frag. Vat. 325 and 326, and C. Th. 2, 1, 4. In its judgment of 12 March 2012, ref. No. P 39/10, the Constitutional Tribunal explained that general local competence is a competence that requires a claim must be filed with the defendant's court. The criteria for determination of the defendant's court in Articles 27-30 of the Code of Civil Procedure are the following: in the case of individuals - place of residence in Poland, place of stay in Poland, and last place of residence in Poland; in the case of legal persons or other entities that are not natural persons - place of their registered office (see also Stankiewicz, 2013).

10) The post-Roman maxim audiatur et altera pars (let the other side be heard also - 14 references) is based on Roman law sources (D. 48, 17, 1 pr.; see also Longchamps de Bérier, 2008). In one of its judgments, the Constitutional Tribunal emphasized that violation of the defendant's right to a fair trial can take the form of deprivation of the defendant of the so-called right to be heard, which is not expressed in the Constitution but is universally considered to be a component of the right to a fair trial. A court's judgment issued based on claims of one party to a proceeding does not constitute "consideration" of a case. There is no doubt that only when the court has heard the arguments of both parties it can analyze the case by weighing the arguments, studying the evidence that has been presented, and considering the claims of the parties, and that only such a procedure followed by the court can be found to constitute consideration of the case (the judgment of the Constitutional Tribunal of 12 March 2002, ref. No. P 9/01).

11) The sentence nemo plus iuris in alium transfere potest, quam ipse habet; also nemo plus iuris ad alium transfere potest, quam ipse habet (no one can transfer to another a greater right than he him- 
self has - 13 references) is based on a text by a Roman jurist Ulpianus (D. 50, 17, 54; see also Amielańczyk, 2008). It expresses one of the fundamental principles of civil law which refers to transfer of ownership. However, in its judgments, the Tribunal indicated exceptions to this principle (the judgment of the Constitutional Tribunal of 20 April 2009, ref. No. SK 55/08).

12) The maxim ei incumbit probatio, qui dicit (the burden of proof lies with the person making the claim - 11 references) is based on Roman law sources (D. 22, 3, 2). In its judgment of 23 May 2012, ref. No. Ts 100/11, the Constitutional Tribunal stated that the principle means that the claimant is required not only to indicate the object and standards of control but also to formulate a relevant argument that present the doubts of the party initiating the proceeding regarding the constitutionality of the regulation that is challenged. The doubts must be supported in a convincing manner that justifies essential consideration of a constitutional complaint.

13) The sentence superficies solo cedit (whatever is attached to the land forms part of it -9 references) is based on numerous Roman law sources (G. 2,73 ; D. 41, 1, 7, 10; D. 41, 1, 9 pr.; D. 41, 1, 9, 1; C. 8, 10, 5). However, the Tribunal emphasized that it is not an absolute principle (the judgment of the Constitutional Tribunal of 19 July 2016, ref. No. Kp 3/15; see also Heliniak, 1999).

14) The maxim nemo iudex in causa sua; also nemo iudex (proprius) in causa sua (no one shall be a judge in his own case - 9 references) is based on the constitution of emperors Valens, Gratian, and Valentinian (C. 3, 5, 1). The Constitutional Tribunal made a reference to this maxim among others in the case related to the bank enforcement title, where it stated that it constitutes an exceptional legal title of banks. In the Tribunal's opinion, this document, originated by a private business entity, replaces the judgment of a court, issued after a court hearing, in which the defendant (debitor) enjoys numerous guarantees that guarantee equal standing of the parties in the process. As a result of the bank enforcement title, banks are literally judges in their own cases and, in fact, judicial bodies, which role, according to Article 175 of the Constitution, can be exercised only by courts of law (the judgment of the Constitutional Tribunal of 14 April 2015, ref. No. P 45/12).

15) The maxim nemo tenetur se ipsum accusare (no one is bound to accuse himself -9 references) is a post-Roman principle that prohibits forcing someone to accuse himself or herself and to provide inculpatory evidence. The essence of this principle is that a defendant should be free to decide whether or not to actively participate in the proceedings con- 
ducted against him or her (the judgment of the Constitutional Tribunal of 30 September 2015, ref. No. K 3/13).

16) The sentence ius civile vigilantibus scriptum est; also vigilantibus, non dormientibus, iura subveniunt (the Civil law is made for those who are diligent in protecting their own rights -8 references) has roots in Roman law (D. 42, 8, 24). The Constitutional Tribunal explained that this principle is commonly accepted in democratic law-abiding states. In the Tribunal's opinion, a clear manifestation of the current validity of this principle is the possibility of an owner-like possessor of a property to acquire it through acquisitive prescription (the judgment of the Constitutional Tribunal of 22 February 2000, ref. No. SK 13/98).

17) The maxim volenti non fit iniuria (to a willing person, injury is not done -7 references) is based on Roman law (D. 47, 10, 1, 5; see also Krzynówek, 2001). In its judgment of 12 December 2005, ref. No. K 32/04, the Constitutional Tribunal noted that law considers "consent" to be a justification for interference in the sphere of the person who has expressed consent.

18) The maxim iura novit curia (the court knows the law -6 references) was formulated in the Middle Ages. In its judgment of 19 June 2012, ref. No. P 41/10, the Constitutional Tribunal stated that this principle, which is undisputed in our legal culture, requires the Tribunal to justify a judgment, without in any case limiting its actions to verification of the positions of the parties to the proceedings.

19) The sentence impossibilium nulla obligatio est (there is no obligation to do the impossible -4 references) is based on a fragment originating from the work of a Roman jurist Celsus (D. 50, 17, 185; see also Dmowski, 2009, 80-81). In one of its judgments, the Constitutional Tribunal stated that the legislator may not impose duties on addressees of law that cannot be performed. It also emphasized that this principle should be an important directive for the legislator in the law-making proces (the judgment of the Constitutional Tribunal of 13 March 2007, ref. No. K 8/07).

20) The maxim leges instituuntur cum promulgantur (laws are instituted when they are promulgated - 3 references) was formulated in the Middle Ages based on the Summa Teologiae by Thomas Aquinas. In one of its judgments, the Constitutional Tribunal explained that the provisions of Article 88, para. 1 of the Constitution make the entry into force of a statute dependent of its promulgation. This condition applies not only to statutes but also to other universally binding normative acts. Other provisions of the Constitution (Article 122, para. 2 and para. 5, and Article 144, para. 3, p. 7) indicate that promulgation of a statute is effected by way of its publication 
in the Journal of Laws; consequently, other methods of publication of the content of a statute are insufficient (the judgment of the Constitutional Tribunal of 20 December 1999, ref. No. K 4/99).

Moreover, in the judgments of the Constitutional Tribunal, other Latin legal maxims can be found, which were used once or twice, such as: $\boldsymbol{e x}$ his quae forte uno aliquo casu accidere possunt iura non constituuntur (laws are not established concerning matters which can only happen in a single instance); dura lex sed lex (the law is harsh, but it is the law); prior tempore potior iure (earlier in time, stronger in law); summum ius summa iniuria (supreme law, supreme injustice; see Longchamps de Bérier, 2005); interest rei publicae, ne maleficia remaneant impunita (it is in the public interest that crimes should not go unpunished); lex iniusta non est lex (unjust law is not the law).

\section{Conclusion}

A review of the judgments of the Polish Constitutional Tribunal that contain Latin legal maxims leads to a number of conclusions. Most of all, the practice of use of Latin sentences has been used continuously from the very beginning of the Tribunal's judicial activity. Interestingly, the very first judgment, announced by the Tribunal on 26 May 1986, ref. No. U 1/86, contained the maxim lex retro non agit.

Currently, in the judgments of the Constitutional Tribunal, Latin maxims define the basic legal principles or solutions both in public and in private law. They also express universal and eternal ideas and are an element of the axiology of law. Most of them were formulated by Roman jurists in the classical period, some by medieval lawyers who knew Roman and canon law, and some by representatives of the modern science of law based on Roman law sources. Given the above, one must agree with the opinion of H. Kupiszewski $(1988,113)$ that "in this area, the Roman law has remained very viable and has become a more or less consciously used element of legal knowledge of contemporary societies and a durable element of the legal culture".

Latin legal maxims present in judgments are also often referred to by parties to proceedings held before the Constitutional Tribunal. Of note is the fact that sometimes maxims that express the same legal principles have different wordings. Applying Latin maxims by the Constitutional Tribunal is visible proof of the persistent nature of the Roman tradition in the development of the history of law. It demonstrates that Latin is an important ele- 
ment of the cultural heritage of ancient Rome and its knowledge constitutes an essential component of legal education. Mastering Latin terminology by a contemporary lawyer - at least the basics of it - is not only evidence of a lawyer's proper preparation for a legal profession, but is also proof of humanist erudition, which should enrich the personality of every jurist.

\section{R E F E R E N C E S}

Amielańczyk, K. 2008. 'O rzymskim pochodzeniu zasady "nemo plus iuris..." i jej aktualności we współczesnym prawie polskim' in W. Witkowski (ed.) $W$ kręu historii $i$ wspótczesności polskiego prawa. Księa jubileuszowa dedykowana profesorowi Arturowi Korobowiczowi, 503-517. Lublin: Wydawnictwo Uniwersytetu Marii Curie-Skłodowskiej.

Bojarski, W. and W. Dajczak, A. Sokala. 2007. Verba iuris. Reguty i kazusy prawa rzymskiego. Toruń: Dom Organizatora.

Burczak, K. and A. Dębiński, M. Jońca. 2013. Eacińskie sentencje i powiedzenia prawnicze. Warszawa: C.H. Beck.

Cieslewicz, N. and S. Sykuna. 2009. 'Prawo karne' in J. Zajadło (ed.) Eacińska terminologia prawnicza, 106-131. Warszawa: Wolters Kluwer.

Dmowski, J. 2009. 'Prawo cywilne' in J. Zajadło (ed.) Lacińska terminologia prawnicza, 59-105. Warszawa: Wolters Kluwer.

Hamza, G. 2013. Origine e sviluppo degli ordinamenti giusprivatistici moderni in base alla tradizione del diritto romano. Santiago de Compostela: Andavira Editora.

Heliniak, K. 1999. 'Zasada "superficies solo cedit" w prawie rzymskim i w przepisach polskiego kodeksu cywilnego'. Czasopismo Prawno-Historyczne, vol. 51 (1-2): 359-369.

Krzynówek, J. 2001. 'Volenti non fit iniuria. Powstanie i historia reguły' in W. Wołodkiewicz and J. Krzynówek (eds.) Eacińskie paremie w kulturze prawnej $i$ orzecznictwie sadów polskich, 267-287. Warszawa: Liber.

Kupiszewski, H. 1988. Prawo rzymskie a wspótczesność. Warszawa: Państwowe Wydawnictwo Naukowe.

Longchamps de Bérier, F. 2005. 'Summum ius summa iniuria. O ideologicznych założeniach w interpretacji starożytnych tekstów źródłowych'. Zeszyty Prawnicze UKSW, vol. 5 (1): 51-68.

Longchamps de Bérier, F. 2008. 'Audiatur et altera pars. Szkic o brakującej kolumnie Pałacu Sprawiedliwości' in W. Uruszczak and P. Święcicka, A. Kremer (eds.) Leges sapere. Studia i prace dedykowane profesorowi Januszowi Sondlowi w pięćdziesiata rocznice pracy naukowej, 271-283. Kraków: Wydawnictwo Uniwersytetu Jagiellońskiego.

Naleziński, B. 2014. 'Organy władzy sądowniczej. Trybunał Konstytucyjny' in P. Sarnecki (ed.) Prawo konstytucyjne Rzeczypospolitej Polskiej, 407-427. Warszawa: C.H. Beck. 
Latin Legal Maxims in the Judgments of the Constitutional Tribunal...

Safarewicz, J. 1986. Zarys historii języka łacińskiego. Wrocław: Zakład Narodowy im. Ossolińskich.

Sondel, J. 1997. Słownik łacińsko-polski dla prawników i historyków. Kraków: Universitas.

Stankiewicz, S. 2013. 'Rzymski rodowód zasady actor sequitur forum rei'. Studia Iuridica Lublinensia, 20: 199-211.

Stein, P. 1999. Roman Law in European History. Cambridge: Cambridge University Press.

Wołodkiewicz, W. 2001. 'Łacińskie paremie prawne w orzecznictwie sądów polskich' in W. Wołodkiewicz and J. Krzynówek (eds.) Eacińskie paremie w kulturze prawnej $i$ orzecznictwie sądów polskich, 7-30. Warszawa: Liber.

Wołodkiewicz, W. 2001. 'Nieznajomość prawa szkodzi. U źródeł zasady ignorantia iuris nocet' in W. Wołodkiewicz and J. Krzynówek (eds.) Eacińskie paremie w kulturze prawnej i orzecznictwie sadów polskich, 109-126. Warszawa: Liber.

Wołodkiewicz, W. 2001. 'Lex retro non agit' in W. Wołodkiewicz and J. Krzynówek (eds.) Eacińskie paremie w kulturze prawnej i orzecznictwie sadów polskich, 153-192. Warszawa: Liber.

Zajadło, J. 2009. 'Teoria i filozofia prawa' in J. Zajadło (ed.) Eacińska terminologia prawnicza, 16-58. Warszawa: Wolters Kluwer.

\section{Internet sources}

System informacji prawnej LEX. https://sip.lex.pl/ 